\title{
How do negative emotions regulate the effects of workplace aggression on counterproductive work behaviours?
}

\begin{abstract}
The theoretical framework of the study was the Stressors-Emotions model (Spector et al., 2005). The aim of the study was to investigate the mediating role of job-related negative affectivity, and the moderating role of emotional suppression in the relationship between workplace aggression and counterproductive work behaviour (CWB). It was expected that workplace aggression would be linked to CWB directly and indirectly (through increase of job-related negative affectivity) and that suppression of negative emotions would intensify the effects of workplace aggression. Two hundred and five nurses participated in the study. The regression analysis with interactional effect was applied to test the research hypotheses. The results confirmed the direct and the indirect effect of workplace aggression on CWB. Two of the three analyzed emotions (anger and anxiety but not unhappiness) moderated the effects of workplace aggression on jobrelated negative affectivity and CWB. Results of the study partially support the notion of the Stress-Emotion model and provide further insight into processes that lead to CWB.
\end{abstract}

Key words: job stressors, counterproductive work behaviour, job-related affectivity, emotional suppression

\section{Introduction}

Counterproductive work behaviours (CWB) are presented in the literature as either a form of retaliation (Bies, Tripp, \& Kramer, 1997; Skarlicki \& Folger, 1997) or a form of a coping with job stressors (Fox, Spector\& Miles, 2001). Regardless of the theoretical context, negative emotions - e.g. anger, hostility, anxiety and unhappiness - are thought to significantly contribute to CWB (Spector, Fox, \& Domagalski, 2005). Resultsof previous studieson the Stress-Emotion (S-E) model have indicated that the link between job stressors and CWB is mediated by these negative emotions (Spector \& Goh, 2001) and moderated by affective dispositions (Bowling \& Eschleman, 2010). The regulating role of negative emotions is particularly evident in the case of social job stressors, including interpersonal conflicts at work (Fox et al., 2001) or workplace aggression (Raver, 2013). However, no studies have tested the moderating effects of emotional suppression in the context of the S-E model. Does the tendency to suppress negative emotions in response to social stressors intensify negative affect at work and CWB, or does it weaken them? The aim of the study was to investigate (1) the direct effect of workplace aggression on CWB; (2) the indirect effect - mediated by negative job-related affectivity and (3) the moderating effect of emotional suppression on workplace aggression - negative affectivity and workplace aggression - CWB links.

\section{Counterproductive work behaviours}

CWB are defined as intentional and justified, from the actors' perspective, acts of employees that are detrimental to organizations, their stakeholders (e.g., clients, co-workers, customers, and supervisors) or both (Fox et al., 2001). It is considered an umbrella term that subsumes, in part or in their entirety, similar constructs that relate to harmful behaviors at work, including organizational aggression (Neuman \& Baron, 1998), antisocial behavior (Giacalone \& Greenberg, 1997), deviance (Robinson \& Bennett, 1995), retaliation (Skarlicki \& Folger, 1997), revenge (Bies, et al., 1997) and mobbing (Zapf, Knorz, \& Kulla, 1996). Specific forms of CWB include abusive behavior against others, aggression (both physical and verbal), purposely doing work incorrectly, sabotage, theft, and withdrawal (e.g., absence, lateness, and turnover) (Spector et al., 2005). The common theme is that these behaviours are harmful to the organization because they directly affect its functioning or property, or hurt employees in a way that reduces their effectiveness.

\footnotetext{
" Department of Psychology, Jan Długosz University in Czestochowa, Poland
} 
These behaviours are a pervasive and costly problem and therefore a topic of great interest to managers and organizational scientists alike. For example, in the United States, between $33 \%$ and $75 \%$ of employees engage in various types of CWB (Bennett \& Robinson, 2000) and the annual estimated cost of CWB is over a $\$ 1$ trillion: $\$ 120$ billion from theft, $\$ 4.2$ billion from workplace violence, and over $\$ 900$ billion in lost income due to fraudulent activities (Banks, Whelpley, \& In-Sue, 2012). Half of the surveyed employees of fast food restaurants and convenience stores confessed to stealing cash and supplies (Wimbush \& Dalton, 1997). In the supermarket industry, the average employee steals $\$ 1,209$ of cash and supplies every year (Jones, Slora, \& Boye, 1990). Harris \& Ogbonna (2002) interviewed workers in the hospitality industry and found $85 \%$ of them engaged in some form of sabotage against their employer and customers on a weekly basis. Romano (1994) reported that more than $20 \%$ of HR managers had dealt with reports of physical violence in the past three years.

\section{The Stressor-Emotion model and the mediating function of negative emotions}

Integrating both the CWB and research literature on job stress, Spector and his co-workers developed the S-E model that assumes the connection from the environment to perceptions, to emotions, and then to CWB (Fox et al., 2001). Specifically, the authors claim that employees monitor and appraise events in their workplace (Lazarus, 1991) - those which are perceived as threats to employees' well-being are defined as job stressors (Spector, 1998). Job stressors can result in CWB directly or indirectly - through the increase of negative emotions. Numerous studies have confirmed that various types of job stressors, including organizational injustice, workload, role conflicts, role ambiguity, organizational constraints and interpersonal conflicts at work are connected with global CWB or its single components (Chen \& Spector, 1992; Spector \& Goh, 2001; Spector et al., 2005). Other studies found that frequent exposure to workplace aggression is linked to different forms of CWB (Mitchell \& Ambrose, 2007, Raver, 2013, Sulea, Fine, Fischmann, \& Sava, 2013).

The central mediating role in the S-E model is attributed to negative emotions at work. Firstly, because they constitute the immediate response to situations that are perceived as stressful (Lazarus, 1991). Secondly, because they energize and motivate behaviours that follow and physiological change (Cartwright \& Cooper, 1997). Such emotions contribute to CWB that can occur immediately and impulsively, or at a later time. Several studies have found evidence of a relationship between negative emotions and job stressors (Spector, 1997; Spector \& Goh, 2001; Szczygieł \& Bazińska, 2013), and also between negative emotions and CWB (Chen \& Spector, 1991; Fox et al., 2001). Other studies have confirmed the mediating role of negative emotions in job stressors - CWB link (Baka \& Derbis, 2013; Ballducci, Fraccaroli, \& Schaufeli, 2011; Fox \& Spector, 1999; Fox et al., 2001). Relying on the cited research (e.g. Fox et al., 2001; Raver, 2013; Sulea et al., 2013) $\mathbf{H 1}$ assumes that experiencing aggression at work is related to CWB directly and indirectly - through an increase in negative emotional states.

\section{Workplace aggression}

Aggression at work is defined as negative acts perpetrated by an organizational member that are experienced by another organizational member who is the target of these acts (Raver, 2013). It can be investigated from actor's and target's perspective. The latter perspective is taken into account in our paper. From this standpoint, workplace aggression is conceptualized as an organizational stressor (Kahn \& Byosiere, 1992) and relates to the frequency with which participants were targets of interpersonally aggressive acts in the workplace. These aggressive acts can occur for a variety of reasons, and a distinction has been made between affective aggression and instrumental aggression (Neuman \& Baron, 1996). Affective, or "hot," aggression has as its primary goal the injury of a target, whether physical or psychological; at times it is impulsive and immediately follows the experience of negative emotion in response to provocation. In turn, instrumental, or "cold", workplace aggression may be a means to achieving a desired end - status, power, perks, assignments, bonuses, promotions, and reputation (Neuman \& Baron, 2005). Aggression in the workplace is quite common. Glomb \& Liao (2003) found that $60 \%$ to $70 \%$ of employees across three organizations he had screened had experienced mild forms of aggression at work, and $6 \%$ of the sample had been physically assaulted at work. Typical forms of workplace aggression include a wide range of behaviours that are intended to harm others such as yelling at someone or threatening them, spreading rumours, making obscene gestures, withholding information, and giving dirty looks (Baron \& Richardson, 1994; Neuman \& Baron, 1996). Previous research confirmed that being the target of workplace aggression is associated with negative emotions and dysfunctional behaviours in organizations (Spector et al., 2005), Poland being no exception (Mościcka \& Merecz, 2003).

\section{Emotional suppression}

The capacity to regulate emotions plays a central role in psychosocial functioning and impacts various important outcomes, including social relationships (Brans, Koval, Verduyn, Lim, \& Kuppens, 2013), physical and mental health (Sapolsky, 2007) and work performance (Diefendorff, Hall, Lord, \& Strean, 2000). Emotional suppression - defined as the conscious inhibition of emotional expression while emotionally aroused (Gross \& Levenson, 1993) - is a type of emotion regulation strategy.It is usually seen as a form of coping, also with job stressors. Emotional suppression involves inhibiting motor or bodily responses to a variety of events at work (Bebko, Franconeri, \& Ochsner, 2007). For example, when the boss makes his employee angry, social norms dictate 
that the latter should hide his outward expression of anger from his boss, even though he is seething with anger at an experiential level.

Findings regarding the physiological and psychological consequences of expressive suppression are mixed. Although occasional studies have found no differences between emotional suppression (e.g. anxiety and anger) and spontaneous reactions (Bush, Barr, McHugo, \& Lanzetta, 1989), the more typical finding is that suppression is associated with increased sympathetic and cardiovascular responses (Gross \& Levenson, 1993), prolonged threats (Kofta, 1979), a decrease in positive emotion-expressive behaviour (Gross \& John, 2003; Szczygieł, Buczny \& Bazińska, 2012), an increase in negative emotions and a decrease in positive emotions experienced in our daily life (Brans et al., 2013). Other studies have found that emotional suppression contributes to a high frequency of aggressive behaviour (Stucke \& Baumeister, 2006) and a high tendency to lie (Butler et al., 2003).

Although previous research on the S-E model indicated that the negative effect of job stressors on CWB is moderated by the emotional disposition of employees, including negative affectivity (Salami, 2010), emotional stability (Penney et al., 2011) and narcissism (Penney \& Spector, 2002), no studies have tested the moderating role of emotional suppression in this context. Based on the cited studies which found that emotional suppression increases negative emotions (Brans, et al., 2013) and aggressive behaviour (Stucke \& Baumeister, 2006), we hope to find that suppression of negative emotions moderates the effect of workplace aggression on job-related negative affectivity (H2) and the frequency of CWB (H3). In other words, employees who suppress negative emotions will demonstrate a high level of job-related negative affectivity and a high level of CWB. The three research hypotheses of this study are presented below.

H1: Workplace aggression is directly and indirectly (through increase of job-related negative affectivity) related to $\mathrm{CWB}$.

H2: Emotional suppression moderates the effect of workplace aggression on job-related negative affectivity.

H3: Emotional suppression moderates the effect of workplace aggression on CWB.

\section{Method}

\section{Research Sample}

Participants of the study were nurses employed in Polish hospitals. Previous studies found that nurses are a vocational group which particularly often experiences workplace violence (Kingma, 2001; Mościcka \& Merecz, 2003). These findings were confirmed by a report issued by the Polish Central Statistical Office Accidents at work and work-related health problems (2014). Potential respondents received a hard copy of the questionnaires along with a letter explaining the purpose of the study. Full confidentiality of data and anonymity were secured. Participants filled out the questionnaires and placed them in envelopes which were collected by research assistants (i.e., three undergraduate students). All participants were treated in accordance with the ethical guidelines of the Helsinki Declaration. Out of the 300 distributed questionnaires, 217 $(72 \%)$ were returned to us and 205 (68\% of the original pool) were at least $75 \%$ complete and were subsequently used in data analyses. The participants were 21 to 60 years old $(M=34.22 ; S D=11.86)$ and their work experience ranged from 1 to 40 years $(M=12.83 ; S D=10.89)$.

\section{Materials}

Aggression at work. The Polish experimental version of Aggressive Experience Scale, AES (Glomb\& Liao, 2003) was used to assess the frequency of being the target of aggression in the workplace. This measure was developed based on Buss's (1961) typology of three behavioural forms of aggression (physical vs. verbal, active vs. passive and direct vs. indirect) and was designed to capture both subtle and severe forms of aggression with a clear intent to harm. It contains 20 items that reflect a range of interpersonal aggressive acts experienced in the workplace (e.g. making angry gestures, spreading rumours, physically assaulting another person). Participants rated the frequency of such experiences on a scale from 1 (never) to 5 (once a week or more). The reliability coefficient - Cronbach's $\alpha-$ of the scale used in the study was a solid 0.96 .

Negative affect at work. This variable was measured with the Polish version of the Job-related affectivity Scale, JAS (Zalewska, 2002), developed by Burke, Brief, George, Roberson, \& Webster (1989). Job-related affectivity is defined conceptually as individuals' emotional reactions to their jobs and to the events that happen in their jobs. It refers to the frequency or the intensity of experiencing positive and negative emotional states at work over a period of time (Burke et al., 1989). JAS contains 20 items which measure the intensity of various affective states experienced at work during the past two weeks, 10 of which are related to negative states (e.g. hostility, anxiety). They include a five-point response scale ranging from 1 (very weekly) to 5 (very strongly). The reliability coefficients for negative affect obtained in the present study was $\alpha=0.89$.

Suppression of negative emotions. The Polish version of Courtauld Emotional Control Scale, CECS (Juczyński, 2001), developed by Watson \& Greer (1983) was used to measure the tendency to suppress negative emotions. The scale consists of 21 items. The authors designed three sub-scales, each comprising of seven items: anger, anxiety and unhappiness. ${ }^{1}$ Exploratory factor analysis confirmed the existence of three factors, relating to three different emotions. All items were scored on a 4-point scale $(1=$ almost never, $4=$ almost always $)$. The reliability coefficient ranged from $\alpha=0.86$ for anger, to $\alpha=0.84$ for anxiety and $\alpha=0.86$ for unhappiness in the study.

\footnotetext{
1 Original questionnaire include three subscales, named anger, anxiety and depression. For the purposes of the article, the depression subscale was renamed with the unhappiness subscale, to highlight emotional aspect of the component.
} 
Counterproductive work behaviour. Counterproductive work behaviours were measured with the Polish version of Counterproductive Work Behavior-Checklist, CWB-C (Macko, 2009), developed by Spector et al. (2006). CWB-C includes 45 items which consist of two subscales - related to organizations (e.g. production deviance, sabotage) and people (e.g. abuse). Participants respond on a five-point scale ranging from 1 (never) to 5 (every day). The general index of the CWB-C was used in this study $(\alpha=0.96)$.

\section{Analytical procedure}

The research model (see Figure 1) was tested by means of regression analysis with bootstrapping, using the PROCESS macros (Hayes, 2013). In comparison with classic mediation and the moderation model (Baron \& Kenny, 1986), PROCESS enables the examination of several mediating and moderating variables in one statistical model. By applying bootstrapping (2000 samples), PROCESS calculates direct and indirect effects and their confidence intervals. The effects of workplace aggression on job negative affect and CWB for low (-1SD), mean $(M)$, and high $(+1 S D)$ levels of the moderators were tested. Separate analyses were run for the simple mediation model (H1) and for the moderation model $(\mathrm{H} 2, \mathrm{H} 3)$, respectively. In the simple mediation model, job-related negative affectivity (the mediator) was first regressed on workplace aggression (path $a$ ) and then CWB was regressed on job-related negative affectivity (path $b$ ) and workplace aggression (path $c$ ). Three separate analyses (each for one of moderator) were conducted. For the analyses, job-related negative affectivity was regressed on workplace aggression (path $a$ ). In the next step, one of three moderators (emotional suppression of anger, anxiety or unhappiness) was included. Next, the interactional effect of workplace aggression $\times$ emotional suppression was added. In the following moderation analyses, CWB were regressed on workplace aggression (path $c$ ), job-related negative affectivity (path $b$ ) and then on the interactional effects of workplace aggression $\mathrm{x}$ emotional suppression.

\section{Results}

Testing the mediation model. $\mathrm{H} 1$ assumed that aggression at work would be associated with CWB and that job-related negative affectivity would act as the mediator of the relationship. The results of regression analysis referring to this hypothesis are presented in Table 1. In the first column, the values for path a (direct link between workplace aggression and negative affectivity) are shown. The second column includes the values for path c' (the direct effect of workplace aggression on CWB) and $b$ (indirect effect of workplace aggression on CWB) successively. The results indicated that the direct effect of workplace aggression on CWB (path $c^{\prime}$ ) is statistically significant, $\mathrm{B}=0.36,95 \%$ bias corrected CI $[0.26,0.46]$ as well as the indirect effect - with job-related negative affectivity as mediator, $B=0.22,95 \%$ bias corrected CI $[0.15,0.29]$, Sobel's $Z=5.31, p<.01$. High aggression was associated with high job-related negative affectivity (path $a$ ), whereas high job-related negative affectivity was related to more frequent CWB (path $b$ ). The data support $\mathrm{H} 1$.

Testing the moderation model. In the next set of analyses $\mathrm{H} 2$ and $\mathrm{H} 3$ were tested, assuming that the effects of workplace aggression on job-related negative affectivity and CWB are moderated by the emotional suppression of three emotions - anger, anxiety and unhappiness. The results of moderation analysis was presented in Table 2, 3 and 4 . Each table contains the results of the moderation analysis for a single moderator-anger suppression (Table 2), anxiety suppression (Table 3 ) and unhappiness suppression (Table 4). The data indicated that aggression in the workplace was linked to job-related negative affectivity (path a). Anger suppression (Table 2, path a), B =0.24, $95 \%$ bias corrected CI $[0.15,0.31]$ and anxiety suppression (Table 3, path a), $B=0.19,95 \%$ bias corrected CI [0.1, 0.29 ] but not unhappiness suppression (Table 4, path a,), $B=0.1,95 \%$ bias corrected CI $[-0.09,0.21]$ moderated the relationship between workplace aggression and jobrelated negative affectivity. Job-related negative affectivity increased along with the increase of workplace aggression, but mainly when anger suppression and suppressing anxiety

Figure 1. Graphic illustration of the investigated dependency

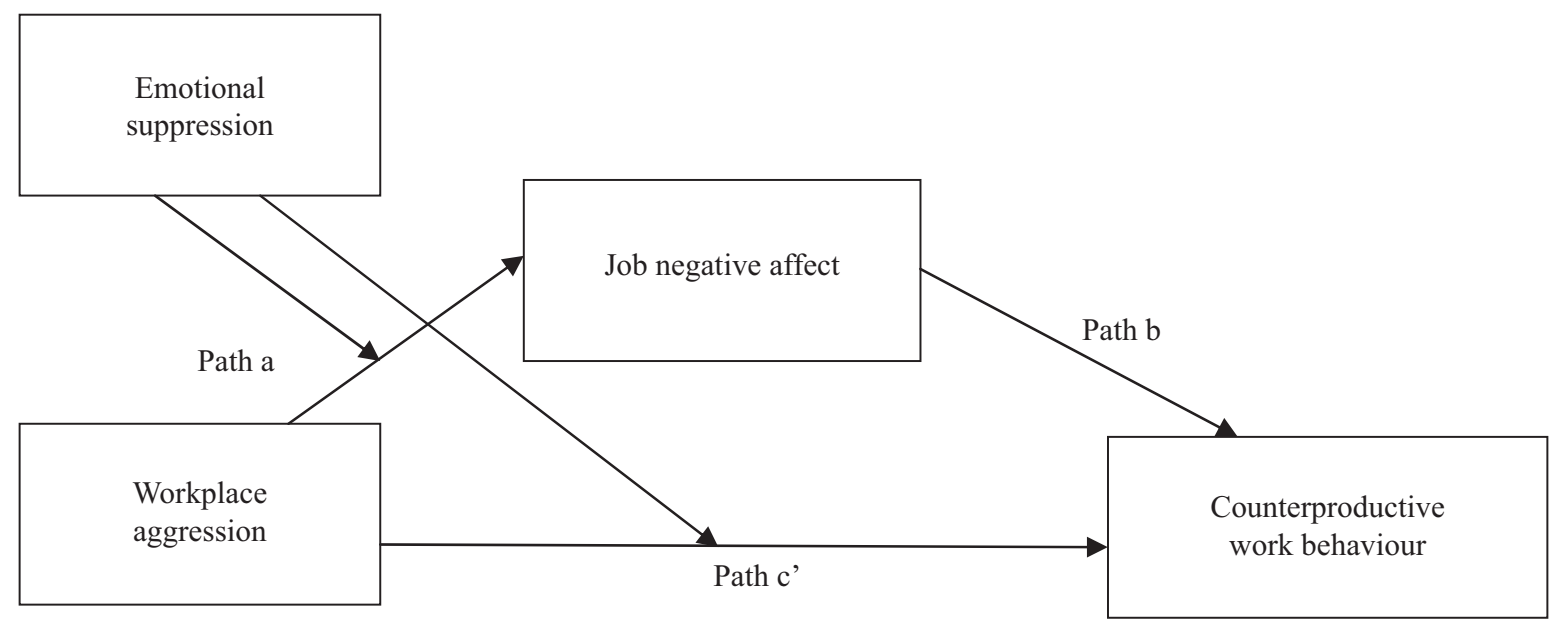


Table 1. Results of regression analyses testing the direct and the indirect effects of workplace aggression on CWB

\begin{tabular}{|c|c|c|c|c|c|c|c|c|c|}
\hline \multirow[t]{2}{*}{ Variable } & \multicolumn{3}{|c|}{$\begin{array}{l}\text { Testing path } a \text { : } \\
\text { Negative affect as a dependent } \\
\text { variable }\end{array}$} & \multicolumn{3}{|c|}{$\begin{array}{c}\text { Testing path } b \text { and } c^{\prime} \text { : } \\
\text { CWB as a dependent variable }\end{array}$} & \multicolumn{3}{|c|}{$\begin{array}{l}\text { Testing path } c \text { (total effect): } \\
\text { CWB as a dependent variable }\end{array}$} \\
\hline & $B$ & $S E$ & $95 \% \mathrm{CI}$ & $B$ & $S E$ & $95 \% \mathrm{CI}$ & $B$ & $S E$ & $95 \% \mathrm{CI}$ \\
\hline Constant & $1.74^{* * *}$ & 0.15 & $\begin{array}{l}{[1.42,} \\
2.05]\end{array}$ & $0.42 * * *$ & 0.1 & $\begin{array}{r}{[0.23,} \\
0.61]\end{array}$ & $0.81 * * *$ & 0.08 & $\begin{array}{l}{[0.64} \\
0.96]\end{array}$ \\
\hline Aggression (X) & $0.63 * * *$ & 0.09 & $\begin{array}{c}{[0.66} \\
0.98]\end{array}$ & $0.36 * * *$ & 0.05 & $\begin{array}{c}{[0.26,} \\
0.46]\end{array}$ & $0.55^{* * *}$ & 0.05 & $\begin{array}{c}{[0.45} \\
0.64]\end{array}$ \\
\hline $\begin{array}{l}\text { Negative affect } \\
\text { (M) }\end{array}$ & & & & $0.22 * * *$ & 0.03 & $\begin{array}{l}{[0.15,} \\
0.29]\end{array}$ & & & \\
\hline
\end{tabular}

NA as $Y: R^{2}=0,31, F=87,64, p<0,001 ; C W B$ as $Y: R^{2}=0,51, F=101,98, p<0,001$; Total effect: $R^{2}=0,41, F=134,28$, $\mathrm{p}<0,001, \mathrm{Z}=5,31, \mathrm{SE}=0,03, \mathrm{p}<0,001$

were high. The lowest increase of job-related negative affectivity was observed among nurses reporting low anger suppression (Figure 2) and low anxiety suppression (Figure 3). H2 was partially confirmed.

Regression analysis testing the direct effect (path c) showed significant main effects of workplace aggression and job-related negative affectivity on CWB. In particular, higher frequency of CWB was related to higher workplace aggression and greater negative affectivity. The analysis of moderating effects showed that two out of three two-way interactions were significant. The link between workplace aggression and CWB was moderated by anger suppression (Table 2, path c), $\mathrm{B}=0.15,95 \%$ bias corrected CI $[0.16$, 0.27 ] and anxiety suppression (Table 3 , path c), $B=-0.16$, $95 \%$ bias corrected CI $[0.37,0.44]$ but not by unhappiness suppression (Table 4, path c), $B=-0.07,95 \%$ bias corrected CI $[-0.07,0.14]$. More thorough analysis revealed that CWB increased along with the increase of workplace aggression but mainly when anger suppression was high (Figure 4) and suppressing anxiety was low (Figure 5). The lowest level of CWB was visible among nurses with low anger suppression and high suppressing anxiety. $\mathrm{H} 3$ was partially supported.

\section{Discussion}

This study addressed questions concerning the relationship between workplace aggression and CWB, as well as the mediating function of job-related negative affectivity and the moderating function of emotional suppression. Drawing on data collected from 205 Polish nurses, it was found that workplace aggression is clearly connected with CWB directly and indirectly - via an increase of job-related negative affectivity. The data supported the S-E model and were consistent with results obtained by other researchers (Fox et al., 2001; Spector et al., 2005). Two of the three emotions moderated the effects of workplace aggression on job-related negative affectivity and CWB. While unhappiness suppression did not act as a moderator, anger and suppressing anxiety moderated both workplace aggression - job-related negative affectivity and workplace aggression - CWB links. Both anger suppression and anxiety suppression intensified the negative effect of workplace aggression on job-related affectivity. When workplace aggression was low the highest level of job-related negative affectivity

Table 2. Results of regression analyses testing the moderating effects of anger suppression

\begin{tabular}{|c|c|c|c|c|c|c|}
\hline \multirow[t]{2}{*}{ Variable } & \multicolumn{3}{|c|}{$\begin{array}{l}\text { Testing path } a \text { : } \\
\text { Negative affect as a dependent variable }\end{array}$} & \multicolumn{3}{|c|}{$\begin{array}{c}\text { Testing path } b \text { and } c^{\prime}: \\
\text { CWB as a dependent variable }\end{array}$} \\
\hline & B & SE & $95 \% \mathrm{CI}$ & B & SE & $95 \% \mathrm{CI}$ \\
\hline Constant & $3.06 * * *$ & 0.07 & {$[2.93,3.19]$} & $1.65 * * *$ & 0.1 & {$[0.86,1.29]$} \\
\hline Workplace aggression (X) & $0.58 * * *$ & 0.09 & {$[0.62,0.96]$} & $0.38 * * *$ & 0.05 & {$[0.27,0.47]$} \\
\hline Anger suppression (Z) & -0.09 & 0.08 & {$[-0.25,0.05]$} & -0.08 & 0.04 & {$[-0.15,0.01]$} \\
\hline Negative affect (M) & - & - & - & $0.19 * *$ & 0.03 & {$[0.12,0.26]$} \\
\hline $\begin{array}{l}\text { Workplace aggression } \\
\mathrm{x} \\
\text { Anger suppression }\end{array}$ & $0.24 * *$ & 0,11 & {$[0.15,0.31]$} & $0.15^{*}$ & 0.06 & {$[0.16,0.27]$} \\
\hline
\end{tabular}

NA as $Y: R^{2}=0,34, F=34,89, p<0,001$

CWB as $\mathrm{Y}-\mathrm{R}^{2}=0,53, \mathrm{~F}=56,71, \mathrm{p}<0,001$ 
Table 3. Results of regression analyses testing the moderating effects of suppressing anxiety

\begin{tabular}{|c|c|c|c|c|c|c|}
\hline \multirow{2}{*}{ Variable } & \multicolumn{3}{|c|}{$\begin{array}{l}\text { Testing path } a \text { : } \\
\text { Negative affect as a dependent variable }\end{array}$} & \multicolumn{3}{|c|}{$\begin{array}{c}\text { Testing path } b \text { and } c^{\prime}: \\
\text { CWB as a dependent variable }\end{array}$} \\
\hline & $B$ & $S E$ & $95 \% \mathrm{CI}$ & $B$ & $S E$ & $95 \% \mathrm{CI}$ \\
\hline Constant & $3.08 * * *$ & 0.07 & {$[2.94,3.21]$} & $1.67 * * *$ & 0.10 & {$[0.84,1.26]$} \\
\hline Workplace aggression (X) & $0.61 * * *$ & 0.09 & {$[0.69,0.99]$} & $0.46^{* * *}$ & 0.05 & {$[0.36,0.57]$} \\
\hline Suppressing anxiety $(\mathrm{Z})$ & -0.08 & 0.09 & {$[-0.21,0.15]$} & -0.06 & 0.04 & {$[-0.16,0.01]$} \\
\hline Negative affect (M) & - & - & & $0.21 * * *$ & 0.03 & {$[0.14,0.27]$} \\
\hline $\begin{array}{l}\text { Workplace aggression } \\
\mathrm{x} \\
\text { Suppressing anxiety }\end{array}$ & $0.19 * *$ & 0,11 & {$[0.1,0.29]$} & $-0.16^{*}$ & 0.06 & {$[0.37,0.44]$} \\
\hline
\end{tabular}

NA as $Y-R^{2}=0,31, F=29,61, p<0,001$

CWB as $\mathrm{Y}-\mathrm{R}^{2}=0,56, \mathrm{~F}=62,16, \mathrm{p}<0,001$

Table 4. Results of regression analyses testing the moderating effects of unhappiness suppression

\begin{tabular}{|c|c|c|c|c|c|c|}
\hline \multirow{2}{*}{ Variable } & \multicolumn{3}{|c|}{$\begin{array}{l}\text { Testing path } a \text { : } \\
\text { Negative affect as a dependent variable }\end{array}$} & \multicolumn{3}{|c|}{$\begin{array}{c}\text { Testing path } b \text { and } c^{\prime}: \\
\text { CWB as a dependent variable }\end{array}$} \\
\hline & $B$ & $S E$ & $95 \% \mathrm{CI}$ & $B$ & $S E$ & $95 \% \mathrm{CI}$ \\
\hline Constant & $3.06 * * *$ & 0.07 & {$[2.92,3.19]$} & $1.63 * * *$ & 0.10 & {$[0.77,1.21]$} \\
\hline Workplace aggression (X) & $0.59 * * *$ & 0.09 & {$[0.59,0.98]$} & $0.39 * * *$ & 0.05 & {$[0.28,0.49]$} \\
\hline $\begin{array}{l}\text { Unhappiness suppression } \\
\text { (Z) }\end{array}$ & -0.003 & 0.09 & {$[-0.18,0.17]$} & -0.01 & 0.04 & {$[-0.15,0.02]$} \\
\hline Negative affect (M) & - & - & & $0.22 * * *$ & 0.03 & {$[0.16,0.29]$} \\
\hline $\begin{array}{l}\text { Workplace aggression } \\
\mathrm{x} \\
\text { Unhappiness suppression }\end{array}$ & 0.1 & 0,12 & {$[-0.09,0.21]$} & -0.07 & 0.06 & {$[-0.07,0.14]$} \\
\hline
\end{tabular}

NA as $Y-R^{2}=0,31, F=29,65, p<0,001$

$\mathrm{CWB}$ as $\mathrm{Y}-\mathrm{R}^{2}=0,51, \mathrm{~F}=52,08, \mathrm{p}<0,001$

Figure 2. The anger suppression moderates the effect of workplace aggression on job-related negative affectivity

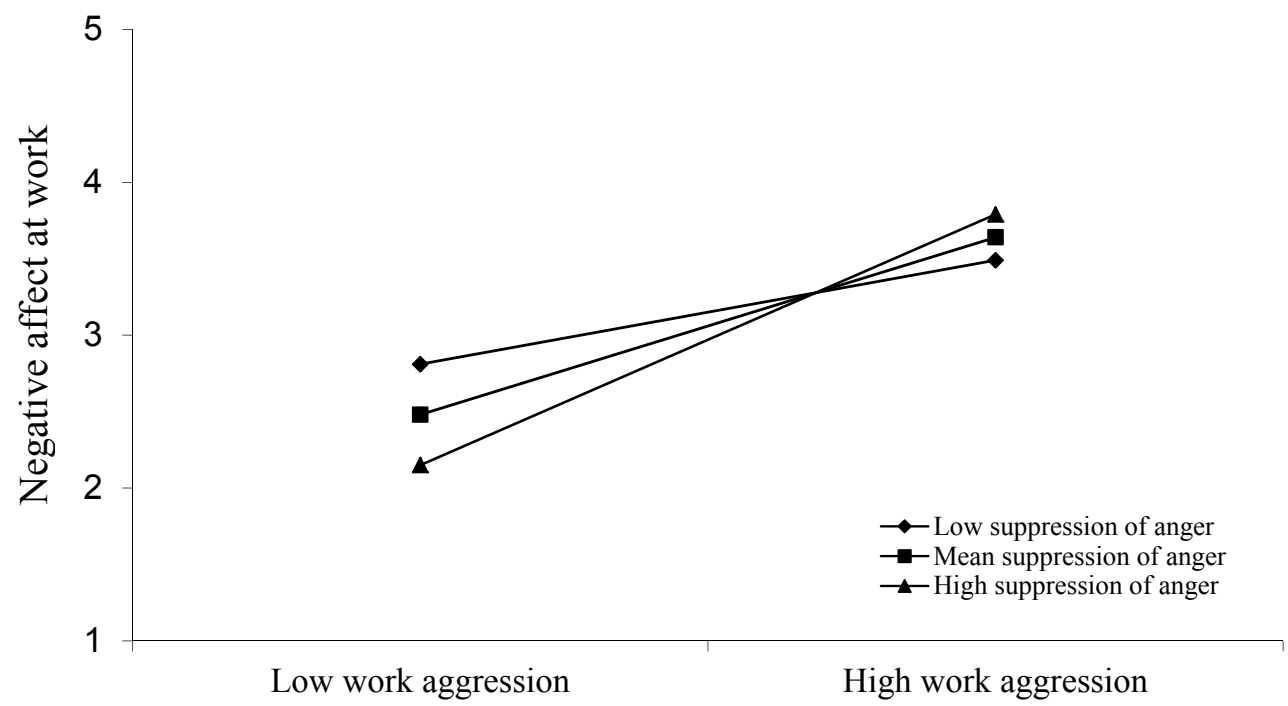


332

Łukasz Baka

Figure 3. The suppressing anxiety moderates the effect of workplace aggression on job-related negative affectivity

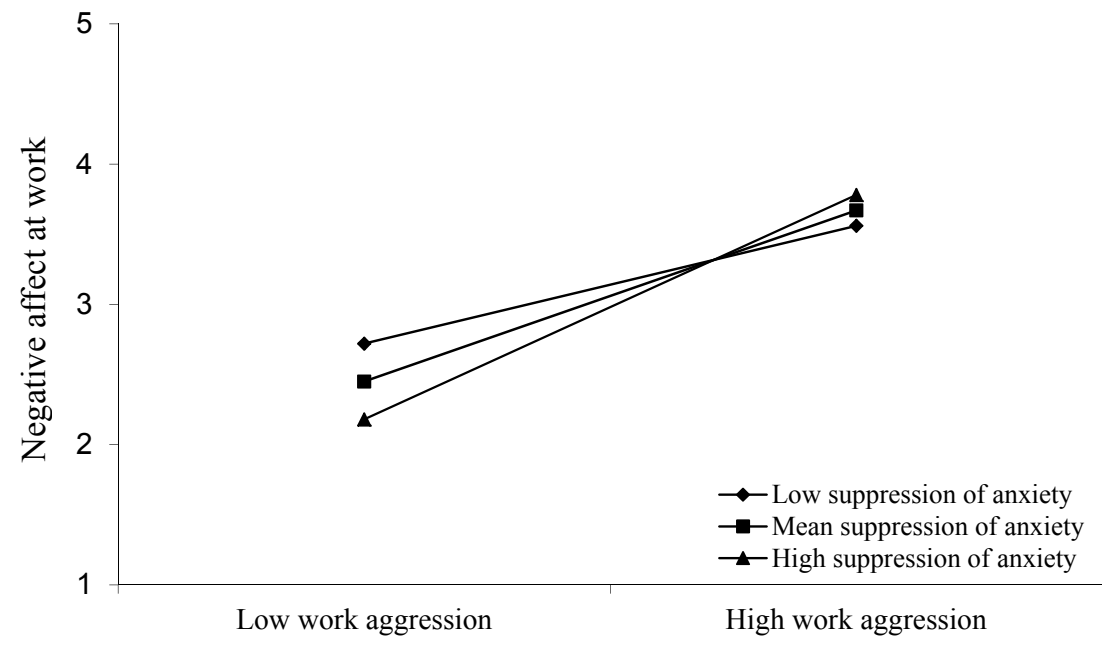

Figure 4. The anger suppression moderates the effect of workplace aggression on CWB

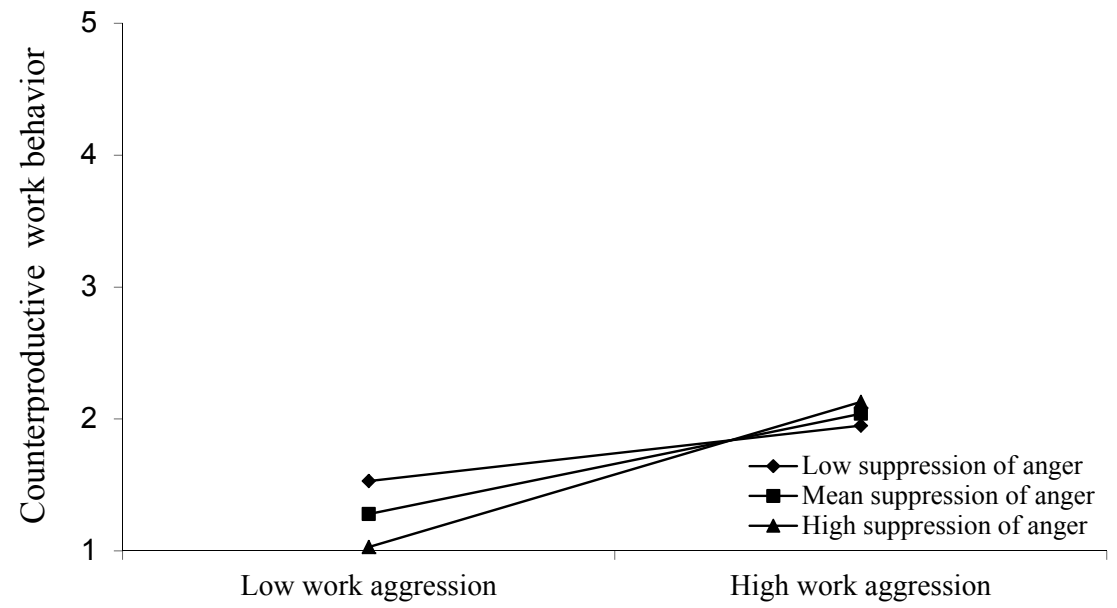

Figure 5. The suppressing anxiety moderates the effect of workplace aggression on CWB

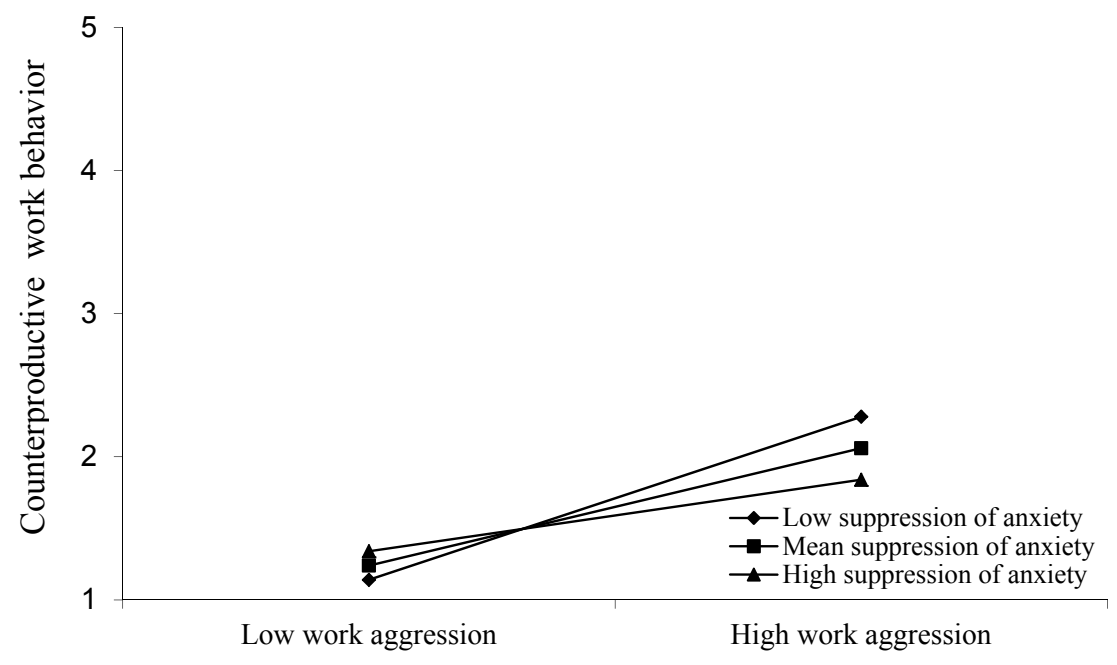


appeared in the group of nurses with low anger suppression and low anxiety suppression. But when workplace aggression increased, the most distinct rise in job-related negative affectivity was observed in the group of nurses with high anger suppression and high rates of suppressing anxiety. The effect was particularly evident in the case of suppressing anger. These results are consistent with those of previous studies that found a direct link between emotional suppression and the experience of negative emotions (Brans et al., 2013) and threats (Kofta, 1979).

Moreover, data analysis revealed that emotional suppression of anger and anxiety moderates the link between workplace aggression and CWB in a different way. Anger suppression intensified the impact of workplace aggression on CWB, while anxiety suppression buffered it. To put it more precisely, the nurses who suppressed anger more intensely in a situation of low workplace aggression displayed the lowest level of CWB. However, in the group of nurses where workplace aggression was higher, CWB increased the most. In case of suppressing anxiety, the opposite regularity was noted. In a situation of low level workplace aggression, the nurses who weakly suppressed anxiety displayed the lowest levels of CWB. However in this very group of nurses, an increase in workplace aggression raised CWB most visibly. This results shed new light on the role of negative emotions in the S-E model and this result is in need of a more detailed explanation.

Both anger and anxiety suppression increased the experience of negative job-related affectivity in the group in question. Probably, the suppression of these two emotional states caused an increase of these emotions most significantly. Long-term experience of these emotional states is unpleasant and over time can trigger some forms of coping. However, the ways of coping are probably different with regard to these two emotions. According to the frustration - aggression theory, to which Fox \& Spector (1999) refer, anger is the main component of frustration and can trigger the tendency to retaliate against organisations in the form of theft, sabotage, production deviance, aggression. By means of these behaviours employees can restore organizational fairness. Other forms of CWB can reduce job stress and its ill-health consequences (Krischer, Penney, \& Hunter, 2010). Taking longer breaks, absenteeism, lateness, production deviance and withholding effort all enable employees to distance themselves from the source of job stress and rebuild depleted resources. To sum up, high levels of job stress (as a result of workplace aggression) combined with strong anger (the result of suppressing emotions) can increase CWB. In contrast, in a situation of high anxiety, such dysfunctional workplace behaviours are not adaptive. The fear of being caught "redhanded" and the threat of revenge from members of the organization probably reinforce subjective anxiety. For that reason, the level of CWB weakens along with an increase of experienced workplace aggression in the group of employees with strong anxiety.

The obtained findings imply further, more detailed questions. One of them is related to the differences in emotional reactions to workplace aggression depending on the position in the organizational hierarchy occupied by the employees. It is likely that, regardless of personality traits, employees allocated highly in the organizational structure will respond with more intense anger to a social stressor but employees who occupy lower positions will experience more intense anxiety. The reaction of employees can be also dependent on the intensity of workplace aggression (mild vs. severe). Additionally, future research can determine whether the suppression of different emotions results in the display of different types of CWB. Maybe the experience of intense anger leads employees towards more active forms of CWB (e.g.: sabotage), whereas the experience of anxiety is conducive to more passive ones (e.g.: withdrawal).

The present study has several limitations. The crosssectional design does not allow for any causal conclusions. CWB are a very changeable phenomena, which result from long-lasting stressors and resources, that is why it is very important to capture the dynamic character of it. Future research needs to apply a longitudinal approach in order to clarify the direction of the relationships between workplace aggression, emotions and CWB. In addition, it should be noted that CWB were measured by statements about organizational behavior, and not by actual behavior or coworkers/supervisors assessment. It seems to be very likely that this variable can be modified by the need for social approval. Therefore, the obtained data should be treated with caution.

Another thing worth commenting on or are the mean values for the CWB-C. In conditions of low workplace aggression, these values are close to 1 (on a five-point scale response - from 1 to 5). This can indicate that the subject shardly confess to harmful behaviors. Probably, the distribution of response sartificially increases the reliability of the CWB-C (Fox, Spector, Goh, Bruursema, \& Kessler, 2012). Many people respond to many items of the scale with 1 (never) and as a result the scale is very reliable because participants' responses are consistent. Most of the previous studies have shown a rather strong negative OCB - CWB link. Theoretically, CWB equates to antisocial behaviors and OCB to prosocial behaviors therefore the behaviors are simply opposites of each other. However Sackett et al. (2006) with a sample of over nine hundred participants used confirmatory factor analysis and found that the two-factor model (OCB and CWB) fit the data significantly. Fox et al. (2012) claim, in turn, that the strong negative association can be inflated by methodological artifacts, such as use of supervisors as raters, an agree rather than a frequency response format, and inclusion of antithetical items in OCB scales (reversed coded CWB). The author concludes that after controlling these artifacts, the relation between OCB and CWB should be too low for the constructs to be treated as one.

The study sample was limited to hospital nurses, therefore any generalization to other human services personnel should not be made. Workgroup variables, such as workgroup identification (Enns \& Rotundo, 2012), need to be more carefully controlled in future studies. Specific negative outcomes in the domain of organization behaviour were addressed, but future studies should carefully investigate 
if similar patterns of associations may be observed for both positive and negative outcomes to the individual and the organization. Regardless of its limitations, the present study provides an insight into the processes explaining counterproductive work behaviours. These findings have implications for further application of the S-E model and other models explaining the occurrence of CWB. Future research should account for both individual and organizational outcomes as well as interactions between them.

\section{References}

Baka, Ł., \& Derbis, R. (2013). Emocje i kontrola w pracy jako regulatory związku stresory w pracy - zachowania nieproduktywne. Empiryczna weryfikacja modelu stresory - emocje [Emotions, job control and effects of job stressors on counterproductive work behaviors. Empirical verification of Stressors-Emotions model]. Psychologia Spoleczna, 8, 323-334.

Baron, R.M., \& Kenny, D.A. (1986. The moderator - mediator variable distinction in social psychological research. Conceptual, strategic and statistical considerations. Journal of Personality and Social Psychology, 51, 1173-1182. doi: 10.1037/0022-3514.51.6.1173

Baron, R.A., \& Richardson, D.R. (1994). Human Aggression, 2nd Edition. New York: Plenum.

Banks, G.C., Whelpley, C.E., \& In-Sue, O. (2012). (How) are emotionally exhausted employees harmful? International Journal of Stress Management, 19, 198-216. doi: 10.1037/a0029249

Bebko, G.M., Franconeri, S.L., Ochsner, K.N., \& Chiao, J.Y. (2011). Look before you regulate. Differential perceptual strategies underlying expressive suppression and cognitive reappraisal. Emotion, 11, 732-742. doi: $10.1037 / \mathrm{a} 0024009$

Bennett, R.J., \& Robinson, S.L. (2000). Development of a measure of workplace deviance. Journal of Applied Psychology, 85, 349-360. doi: 10.I037//0021-9010.85.3.349

Bies, R.J., Tripp, T.M., \& Kramer, R.M. (1997). At the breaking point: Cognitive and social dynamics of revenge in organizations. In R.A. Giacalone \& J. Greenberg (Eds.), Antisocial behavior in organizations (pp. 18-36). Thousand Oaks, CA: Sage.

Bowling, N.A., \& Eschleman, K.J. (2010). Employee personality as a moderator of the relationships between work stressors and counterproductive work behavior. Journal of Occupational Health Psychology 12, 91-103. doi: 10.1037/a0017326

Brans, K., Koval, P., Verduyn, P., Lim, Y.L., \& Kuppens, P. (2013). The regulation of negative and positive affect in daily life, Emotion, 13 , 926-939.doi:10.1037/a0032400

Burke, M.J., Brief, A.P., George, J.M., Roberson, L.I., \& Webster, J. (1989). Measuring affect at work: Confirmatory analyses of competing mood structures with conceptual linkage to cortical regulatory systems. Journal of Personality and Social Psychology, 57, 1091-1102. doi: 10.1037/0022-3514.51.6.1173

Bush, L.K., Barr, C.L., Mchugo, G.J., \& Lanzetta, J.T. (1989). The effects of facial control and facial mimicry on subjective reactions to comedy routines. Motivation and Emotion, 13, 31-52. doi: $10.1080 / 02699930143000194$

Buss, A.H. (1961). The psychology of aggression. New York: John Wiley \& Sons.

Butler, E.A., Egloff, B., Wilhelm, F.H., Smith, N.C., Erickson, E.A., \& Gross, J.J. (2003). The social consequences of expressive suppression. Emotion, 3, 48-67. doi: 10.3758/MC.36.3.604

Cartwright, S., \& Cooper, C.L. (1997). Managing Workplace Stress. Thousand Oaks, Ca: Sage.

Chen, P.Y., \& Spector, P.E. (1991). Negative affectivity as the underlying cause of correlations between stressors and strains. Journal of Applied Psychology, 76, 398-407. doi: 10.1037/0021-9010.93.1.95

Chen, P.Y., \& Spector, P.E. (1992). Relationships of work stressors with aggression, withdrawal, theft and substance use: An exploratory study. Journal of Occupational and Organizational Psychology, 65, 177-184. doi: 10.1111/j.2044-8325.1992.tb00495.x

Diefendorff, J.M., Hall, R.J., Lord, R.G., \& Strean, M.L. (2000). Actionstate orientation: Construct validity of a revised measure and its re- lationship to work-related variables. Journal of Applied Psychology, 85, 250-263. doi: 10.1037/0021-9010.85.2.250

Enns, J.R., \& Rotundo, M. (2012). When competition turns ugly: Collective injustice, workgroup identification, and counterproductive work behavior. Human Performance, 25, 26-51. doi:10.5465/ amr.2011.0109

Fox, S., \& Spector, P.E. (1999). A model of work frustration-aggression. Journal of Organizational Behavior, 20, 915-931. doi: 10.1002/ (SICI)1099-1379(199911)20:6<915::AID-JOB918>3.0.CO;2-6

Fox, S., Spector, P., Goh, A., Bruursema, K., \& Kessler, S. (2012). The deviant citizen: Measuring potential positive relations between counterproductive work behaviour and organizational citizenship behavior. Journal of Occupational and Organizational Psychology, 85, 199-220. doi: 10.1111/j.2044-8325.2011.02032.x

Fox, S., Spector, P.E., \& Miles, D. (2001). Counterproductive work behavior (CWB) in response to job stressors and organizational justice: Some mediator and moderator tests for autonomy and emotions. Journal of Vocational Behavior, 59, 291-309. doi: 10.1006/ jvbe. 2001.1803

Giacalone, J., \& Greenberg (Eds.), Antisocial behavior in organizations. Thousand Oaks, CA: Sage.

Glomb, T.M., \& Liao, H. (2003). Interpersonal aggression in work groups: Social influence, reciprocal, and individual effects. Academy of Management Journal 46, 486-49. doi: 10.2307/30040640.

Gross, J.J., \& John, O.P. (2003). Individual differences in two emotion regulation processes: Implications for affect, relationships, and wellbeing. Journal of Personality and Social Psychology, 85, 348-362.doi: 10.1037/0022-3514.85.2.348

Gross, J.J., \& Levenson, R.W. (1997). Hiding feelings: The acute effects of inhibiting negative and positive emotion. Journal of Abnormal Psychology, 106, 95-103. doi.org/10.1037/0021-843X.106.1.95

Harris, L.C., \& Ogbonna, E. (2002). The unintended consequences of culture interventions: A study of unexpected outcomes. British Journal of Management, 13, 31-49. doi: 10.1111/1467-8551.00221

Hayes, A.F. (2013). An introduction to mediation, moderation, and conditional process analysis: A regression-based approach. New York: Guilford Press.

Jones, J.W., Slora, K.B., \& Boye, M.W. (1990). Theft reduction through personnel selection: A control group design in the supermarket industry. Journal of Business\& Psychology, 5, 275-279. doi:10.1037/0021-9010.82.5.756

Juczyński, Z. (2001). SkalaKontroli Emocji - CECS [Emotional Contro Scale-CECS] InZ. Juczyński, (Eds.), [Measure tool in the promotion health and psychology health]. Warszawa: Pracownia Testów Psychologicznych PTP.

Kahn, R.L., \& Byosiere, P. (1992). Stress in organizations. In: M. D. Dunnete\& L. M. Hough (Eds.), Handbook of industrial and organizational psychology, vol. 3, pp. 537-650. Palo Alto, CA: Consulting Psychological Press.

Kingma, M. (2001). Workplace violence in the health sector: a problem of epidemic proportion. International Nursing Review, 48, 129-130. doi: $10.1111 / j .1547-5069.2009 .01321 . x$

Knorz, C., \& Zapf, D. (1996). Mobbing-Eine extreme Form sozialerStressoren am Arbeitsplatz,. ZeitschriftfuerArbeits- und Organizations Psychologie, 40, 12-21.

Kofta, M. (1979). Self-control and emotions. Warsaw: Polish Scientific Publishers.

Krischer, M.M., Penney, L.M., \& Hunter, E.M. (2010). Can counterproductive work behaviors be productive? CWB as emotion - focused copying. Journal of Occupational Health Psychology, 15, 154-166. doi: $10.1037 / \mathrm{a} 0018349$

Lazarus, R.S. (1991). Psychological stress in the workplace. In P.L. Perrewe (Eds.), Journal of Social Behavior and Personality: Vol. 6. Handbook on job stress(special issue) (pp. 1-13). San Rafael, CA: Select Press.

Macko, M. (2009). Poczucie sprawiedliwości organizacyjnej a zachowania pracowników. [Organizational justice and the employee behaviours] Poznań: Wydawnictwo Naukowe Wydziału Nauk Społecznych Uniwersytetu Adama Mickiewicza w Poznaniu.

Mitchell, M.S., \& Ambrose, M.L. (2007). Abusive supervision and workplace deviance and the moderating effects of negative reciprocity beliefs. Journal of Applied Psychology, 92, 1150-1168. doi org/10.1037/0021-9010.92.4.1159 
Mościcka, A., \& Merecz, D. (2003) Aggression at workplace - sources, forms, risk groups and consequences, Occupational Medicine, 54, $361-368$.

Neuman, J.H., \& Baron, R.A. (1996). Aggression in the workplace. In: R.A. Giacalone, J. Greenberg (Eds.), Antisocial behavior in organizations (pp. 37-67). Thousand Oaks, CA: Sage.

Neuman, J.H., \& Baron, R.A. (2005). Aggression in the workplace: A social psychological perspective. In S. Fox, P.E. Spector (Eds.), Counterproductive work behavior:Investigations of actors and targets (pp. 13-40). Washington, DC: American Psychological Association.

Neuman, J. H., \& Baron, R. A. (1998). Workplace violence and workplace aggression: Evidence concerning specific forms, potential causes, and preferred targets. Journal of Management, 24, 391-419. doi: $10.1037 / \mathrm{a} 0018349$

Penney, L.M., \& Spector, P.E. (2002).Narcicism and counterproductive work behavior (CWB). Do bigger egos mean bigger problems? International Journal of Selection Assessment, 10, 126-134 doi: 10.1111/1468-2389.00199

Penney, L.M., Hunter, E.M., \& Perry, S.J. (2011). Personality and counterproductive work behavior: Using conservation of resources theory to narrow the profile of deviant employees. Journal of Occupational and Organizational Psychology, 84, 58-77. doi: 10.1111/j.20448325.2010.02007.x

Raver, J.L. (2013). Counterproductive Work Behavior and Conflict: Merging Complementary Domains. Negotiation and Conflict Management Research, 6, 151-159. doi: 10.1111/ncmr.12013

Richards, J.M., \& Gross, J.J. (1999). Composure at any cost? The cognitive consequences of emotion suppression. Personality and Social Psy chology Bulletin, 25, 1033-1044. doi: 10.1177/01461672992511010

Robinson, S.L., \& Bennett, R.J. (1995). A typology of deviant workplace behaviors: A multidimensional scaling study. Academy of Management Journal, 38, 555-572. doi: 10.I037//0021-9010.85.3.349

Sackett, P.R., Berry, C.M., Wiemann, S.A., \& Laczo, R.M. (2006). Citizenship and counterproductive behaviour. Clarifying relations between the two domains. Human Performance, 19, 441-464. doi: 10.1207/s15327043hup1904_7

Salami, A.O. (2010). Job stressors and counterproductive work behaviour Negative affectivity as a moderator. The Social Science, 5, 486-492.

Sapolsky, R.M. (2007). Stress, stress-related disease, and emotion regulation. In: J.J. Gross (Eds.), Handbook of emotion regulation (pp. 606-615). New York, NY: Guildford Press.

Skarlicki, D.P., \& Folger, R. (1997). Retaliation in the workplace: The roles of distributive, procedural, and interactional justice. Jour- nal of AppliedPsychology, 82, 434-443.doi.org/10.1037/00219010.82.3.434

Spector, P.E. (1998). A control model of the job stress process. In C.L. Cooper (Eds.), Theories of Organizational Stress (pp. 153-169). London: Oxford University Press.

Spector, P.E. (1997). The role of frustration in antisocial behavior at work In R.A.Giacalone \& J. Greenberg (Eds.), Antisocial behavior in organizations (pp. 1-17). Thousand Oaks, CA: Sage.

Spector, P.E., Fox, S., \& Domagalski, T. (2005). Emotions, violence and counterproductive work behavior. In E.K. Kelloway, J. Barling, \& J.J. Hurrell (Eds.), Handbook of workplace violence (pp. 29-46). Thousand Oaks, CA: Sage.

Spector, P.E., \& Goh, A. (2001). The role of emotions in the occupational stress process. In P.L. Perrewé, \& D.C. Ganster (Eds.), Research in occupational stressand well-being. Greenwich, CT: JAI.

Spector, P.E., Fox, S., Penney, L.M., Bruursema, K., Goh, A., \& Kessler, S. (2006). The dimensionality of counterproductivity: Are all counterproductive behaviors created equal? Journal of Vocational Behavior, 68, 446-460. doi: 10.1016/j.jvb.2005.10.005

Stucke, T.S., \& Baumeister, R.F. (2006). Ego depletion and aggressive behavior. Is the inhibition of aggression a limited resource? European Journal of Social Psychology, 36, 1-13.doi: 10.1002/ejsp.285

Sulea, C., Fine, S., Fischmann, G., \& Sava, F.A. (2013). Abusive supervision and counterproductive work behaviors. The moderating effects of personality. Journal of Personell Psychology, 12, 196-200. doi: 10.1027/1866-5888/a000097

Szczygieł, D., \& Bazińska, R. (2013). Emotional intelligence as a moderator in the relationship between negative emotions and emotional exhaustion among employees in service sector occupations. Polish Psychological Bulletin, 44, 75-86. doi: 10.2478/ppb-2013-0023

Szczygieł, D., Buczny, J., \& Bazińska, R. (2012). Emotion regulation and emotional information processing: The moderating effect of emotional awareness. Personality and Individual Differences, 52, 433-437. doi:10.1016/j.paid.2011.11.005

Watson, M., \& Greer, S. (1983). Development of a questionnaire measure of emotional control. Journal Of Psychosomatic Research, 27, 299-305. doi: 10.1017/S0033291700002026

Wimbush, J.C., \& Dalton, D.R. (1997). Base rate for employee theft: Convergence of multiple methods. Journal of Applied Psychology, 82, 756-763.doi: 10.1037/0021-9010.82.5.756

Zalewska A.M., (2002) Skala afektu w pracy - wstępne wyniki prac nad adaptacją techniki [Job Affect Scale. Preliminary results of adaptation tools], Studia Psychologiczne, 2002, 40, 172-192. 